Nierówności Społeczne a Wzrost Gospodarczy, nr 60 (4/2019)

Social Inequalities and Economic Growth, no 60. (4/2019)

DOI: $10.15584 /$ nsawg.2019.4.11

ISSN 1898-5084, eISSN 2658-0780

Barbara Oliwkiewicz, $P h D^{1} \odot$

Andrzej Frycz Modrzewski Krakow University

Department of Accountancy

\title{
Protection of human capital against depreciation as the primary reason for providing compensation ${ }^{2}$
}

\section{INTRODUCTION}

Family is the only supplier of human capital for the labour market. Fair pay for an employee is a prerequisite for maintaining an appropriate level of human capital in a household. The pay should be at a level enabling the employee and their family to satisfy their basic needs in order to regenerate their capacity for work and to develop their personality. The right to a fair pay is one of the major norms regulating human rights. The employee compensation level has a substantial impact on the emotional condition of the beneficiary (Karaszewska, 2003, p. 67). It was already Theodore Shultz, one of the precursors of the human capital theory, who noticed that a country's development and its dynamic largely depended on the human capital of its citizens (Dobija, 2003, pp. 150-151). The knowledge, experience and physical condition of people are all significant productivity factors. So it is important to create appropriate conditions in the country for proper development of the components of human capital. The size and stability of income are treated as measures of an individual's social value. They also determine the individual's place in the hierarchy and assign them to specific social strata.

From the employer's point of view, employee compensation has various functions, incentive being an important one. For the compensation to serve as an incentive, the employee must find it satisfying. And an employee can be satisfied with their compensation only if they consider it fair. As has already been mentioned, a fair pay permits regenerating at least the same level of human capital, both in the short term and in the long run. Additionally, pay amount impacts more than just

${ }^{1}$ Correspondence address: e-mail: boliwkiewicz@afm.edu.pl. ORCID 0000-0002-0752-2288.

${ }^{2}$ The article was subsidised from funds intended for the charter-based activities of the Andrzej Frycz Modrzewski Krakow University's School of Management and Communications no. WZiKS/ DS/3/2017-KON. 
the performance of the contract between the employer and the employee - it also indirectly influences the image of the company as an employer. The compensation solutions applied by a business entity should be structured to serve as an incentive for employees with appropriate qualifications (Borkowska, 2001, p. 21).

The purpose of this article is to present the role of family in shaping human capital and to attempt to estimate the minimum fair pay in Poland that permits regenerating the human capital, both in the short term and in the long run - through generational change.

\section{HUMAN CAPITAL MODEL}

The compound interest formula is crucial for the capital growth model. Compound interest is a solution where interest from a cash contribution for a particular period is compounded and as such contributes to the profit generated in the next period. Albert Einstein once said that compound interest is the 8th wonder of the world and called it the greatest mathematical discovery of all time and the most powerful force in the universe. There is no exaggeration in this opinion as it is indisputably an effective and practical model. The confirmation of these words can be found in the story of Warren Buffett, whom the fascination with compound interest has enabled to make billions of dollars in an honest way (Bednarski, Dobija, 2003). The simple formula for continuously compounded interest is as follows:

$$
C_{t}=C_{0} \times e^{r t}
$$

where:

$C_{t}-$ end capital,

$C$ - initial capital,

e - Euler's number,

$\mathrm{t}$ - number of years until deposit maturity date,

$r$ - nominal annual interest rate

Formula (1) presents the simplest model of capital growth in the economy and it can be derived from the fundamental accounting principle of duality. According to that principle, property resources are disclosed dually - both as assets and as the capital concentrated therein (Dobija, 2003). So, the issues of ownership aside as they will have no impact on the nature of the discussion, the duality principle will be presented through the simple formula:

$$
A_{0}=C_{0}
$$

where: $A_{0}$ - the value of the assets at the beginning of the period, $C_{0}$ - the value of the capital at the beginning of the period. 
Formula 2 requires identifying the essence of the capital. Assuming that the asset is just one excavator, the current capital may be the abstract capacity of the excavator to perform work. As time goes by, the excavator loses its capacity for work, even if it stands idle. The potential of the excavator did not come from nothing but it was created in the manufacturing process. The capacity for work is the guarantee for the existence of both machines and people. Only living people are the carriers of human capital, while machines and equipment having no capacity for work are scrapped. An analysis of the above deliberations shows that the duality concept and the Debit-Credit rule make it impossible to produce capital out of nothing. Capital cannot be created so the formula presenting the growth of capital includes the initial capital $C_{0}$.

It is common knowledge that profit is a periodic capital growth so by using a basic accounting equation, we obtain Formula 3:

$$
\text { Profit }=\Delta C=\Delta A
$$

where:

$\Delta C$ - the difference between value of the capital at the end and at the beginning of the analysed period,

$\Delta A$ - the difference between value of the assets at the end and at the beginning of the analysed period.

Afterwards, we may use the above values to calculate the rate of return:

$$
R O A=\frac{\Delta C}{C_{0}}=\frac{\Delta A}{A_{0}}
$$

where: $R O A$ - rate of return.

So the capital after the initial reporting period is as follows: $C_{1}=C_{0}\left(1+R O A_{1}\right)$, and after subsequent n periods: $C_{n}=C_{0}\left(1+R O A_{1}\right) \times \ldots \times\left(1+R O A_{n}\right)$. Accordingly, there is a mean ROA for which: $C_{n}=C_{0}(1+R O A)^{n}$. This results in Formula 5:

$$
C_{1}=C_{0} \times e^{R O A t}
$$

where: $t$ - reporting period (period of time).

Since the capital grows according to Formula 5, many scientists use this formula as the starting point for their deliberations regarding growth. As we continue, we should also address the issue of the growth rate structure. Research has shown (Dobija, 2007) that the ROA rate of return is a total of three components 
which have a substantial impact on the end value of the capital (Dobija, Renkas, 2011, p. 182). In view of the foregoing, the capital growth model is as follows (Dobija, 2009):

$$
\left.C_{t}=C_{0} \times e^{(p-s+m) t}, p=E(s)=0.08 \text { [1/year }\right]
$$

where:

$p$ - economic constant of potential growth (ECPG);

$s$ - natural spontaneous capital dispersion rate;

$m$ - capital growth rate resulting from capital inflow through work processes.

Presented below is the interpretation of the forces acting in the law of exponential growth:

$e^{p t}-$ a component expressing the natural capital growth capacity that is attainable due to the properties of the world we live in, governed by the laws of nature - the economic constant of potential growth (ECPG) $p=0,08$ [1/year];

$e^{-s t}$ - a component presenting the impact of the thermodynamic arrow of time as random capital dispersion (the impact of the second law of thermodynamics), $t$ - calendar time;

$e^{m t}-$ a component representing actions that boost capital growth through management and work performance and eliminate the impact of the thermodynamic arrow of time.

It must be noted that the right side of the equation (6) is the initial capital, which - according to the first law of thermodynamics - does not come from nothing. Only if already acquired, capital may change - as a result of the income derived from natural sources and from work, and may be dispersed. An individual with their human capital is a perfect example to illustrate those statements. At the moment of birth, the child already has its initial capital $\left(C_{0}\right)$, which would undergo dispersion without the care of its parents $\left(e^{-s t}\right)$, thus resulting in the infant's death. The efforts of the parents and the society compensate for the dispersion of the capital and guarantee its existence $\left(e^{m t}\right)$, while its growth rate is determined by the $p$ constant.

An analysis of the capital model reveals that work is not the only or even the main growth factor. All that work does is reduce the impact of the thermodynamic arrow of time $\left(e^{-s t}\right)$. As physiocrats used to claim, work is futile but only in the sense that work transfers the capital rather than increasing its amount in the general balance of capital. To be able to work, one must first accumulate human capital, i.e. the capacity for work. Work transfers the capital but it cannot increase it. However, without work, the spontaneous capital dispersion ' $s$ ' would reduce the natural growth potential that we owe to Nature.

So assuming that an individual is the owner of their human capital, we obtain a formula for the human capital of an employee $\left(H_{t}\right)$ where the capital depends on 
the initial investment $\left(H_{0}\right)$, the economic constant $(p)$ and the compounding time $(t)$. The general capital model, with the assumption that $s=m$, leads to the following general formula for human capital:

$$
H_{t}=H_{0} e^{p t}
$$

Formula 7 presents the significance of the constant of potential growth in the calculation of human capital. It must be noted that the variable $H_{0}$ is not a onetime investment but a stream of investments (costs of living, costs of professional education) (Dobija, 2010, p.77).

\section{RULES OF PAYING FOR HUMAN CAPITAL}

According to the theory of human capital and fair compensation, as has been mentioned above, work means the transfer of human capital to the objects of work. Compensation for work is the cash equivalent paid to the employee in exchange for providing human capital. The rules of paying for human capital depend on the nature of the capital. The pay model must take into account the impacts of the environment on changes in human capital and its natural capacity for growth. The initial value of human capital is influenced by random dispersion, which leads to gradual loss of its value. To preserve the value of human capital, the pay must reduce the natural losses of the capital. For physical resources, the dispersion of value is driven by the deterioration of their condition in connection with the passing of time (e.g. metal parts of a car corrode as time goes by). Preservation of the initial capital requires a continuous inflow of value to balance out the natural capital dispersion. So the value of the capital will be guaranteed if the assets where the capital is allocated create a stream of inflows leading to a proportionate rate of return. The rate of return should not be lower than the compounding rate, otherwise the value of the capital will drop to below its purchase value (Dobija, 2002, pp. 8-13).

An employee's human capital decreases as a result of the effort related to work and in connection with the passing of time. The pay is to compensate the loss of human capital and its amount should arise from the application of the economic constant or potential growth. Empirical studies in a number of publications (Dobija, 1998; Cieślak, 2008; Kozioł, 2010; Kurek, 2011; Renkas, 2012) confirm that the constant is about $8 \%$ per annum.

A general capital model includes various categories that represent active measures and potential measures. It must be noted that the $s$ variable represents active forces of nature, while the $m$ variable stands for measures in the form of work-related capital inflow, which may balance out the dispersion of the capital. The economic constant of potential growth $p$ is the symbol of potential forces. The $p$ 
constant determines the natural potential that guarantees human capital growth only on condition that the $s$ dispersion level is compensated by the $m$ measure. If $s=m$, the human capital grows at a rate $p=8 \%$. Sometimes $m$ may actually be bigger than $s$ (e.g. due to specialised and professional education), which means that the human capital growth rate will be faster than $p=8 \%$. However, the situation may also be opposite, where the $m$ balances out the $s$. In such a case, the capital growth rate is lower than $p=8 \%$, which may bring the demise of the individual (Oliwkiewicz, 2018, pp. 369-370). So a pay that balances out the outflow of the employee's human capital can be established based on the mean value $E$ :

$$
\mathrm{W}=\mathrm{E}(\mathrm{s} \times \mathrm{H})=\mathrm{E}(\mathrm{s}) \mathrm{H}=\mathrm{p} \times \mathrm{H}
$$

where: $W$ - basic salary, $p$ - economic constant of potential growth, $H$ - value of employee's human capital.

\section{FAMILY VERSUS THE PROCESS OF SHAPING HUMAN CAPITAL}

The level of human capital in a household substantially depends on the living conditions of the family, especially its disposable income, expenses, and the institutional environment, which may either support or hinder the development of human capital. The passing of time is always accompanied by outflow of human capital so the task of a household is to regenerate it, both in the short term and in the long run. Human capital regeneration short term means replenishing the vital energy lost during daily tasks (e.g. through meals, rest, sleep, etc.). Preparing children to work and live in the society is a set of actions taken to regenerate human capital in the long run. Economic progress requires using such solutions in the preparation of the next generations for work to make them at least as prepared as their predecessors. Those objectives are only attainable if all family members take appropriate actions in an economic dimension. This is especially about economic relations with the units that create the market environment and the institutional environment for the household. A household is the only supplier of human capital and employment is the most important element of its cooperation with the environment. The household is remunerated for the provision of human capital and it spends the money primarily to cover the costs of regenerating the human capital, both in the short term and in the long run. So the pay level is particularly important from the point of view of the dynamic of the household's human capital in the long term. The income of the family should be at a level balancing out the dispersing forces - it should be based on the $8 \%$ economic constant.

Fair compensation of an employee with primary education in a family of four was estimated based on the measurement of human capital and fair pay. The model used the assumptions that applied to Poland's economic situation 
for 2018. The costs of living were based on the subsistence minimum published annually by the Institute of Labour and Social Studies (IPiSS). Subsistence minimum is a category representing the costs of living of modest households which are established at a level securing the conditions that allow people to replenish their vital energy at any time, to have and raise children and to maintain bonds with the society (Deniszczuk, 1977). It must also be added that the costs should be calculated as the costs of living of one person in a model of working family of four (a prerequisite for the human capital to be regenerated in the long run). The monthly costs of living at the subsistence minimum level in June 2018 were PLN 941.34 (Kurowski, 2018). The model takes into account only the costs that fall within the limits of necessary consumption (are socially justified), so the subsistence minimum of PLN 941.34 is recommended to be reduced by $10 \%$. The resulting socially justified costs are PLN 847 [PLN 941 - (PLN 941×10\%)] a month. For an employee with primary education, human capital will be calculated according to the following formula:

$$
H(T)=K
$$

where:

$H(T)$ - the value of human capital, $K$ - compounded costs of living for 18 years, $T=0$

Presented below are formulas illustrating the formation of human capital from the costs of living:

Table 1. Formulas illustrating the formation of human capital

\begin{tabular}{|l|c|}
\hline & Costs of living \\
\hline Annual compounding & $K_{t}=k \times 12 \times \frac{(1+p)^{t}-1}{p}$ \\
\hline Continuous compounding & $K_{t}=k \times 12 \times \frac{e^{p t}-1}{p}$ \\
\hline
\end{tabular}

Source: own work (Oliwkiewicz, 2016, p. 484).

where:

$K_{t}$ - compounded costs of living,

$\mathrm{k}$ - necessary monthly costs of living,

$t$ - number of compounding years for the necessary costs of living.

Estimation of the human capital value and the minimum fair pay for an employee with primary education: data: $k=\operatorname{PLN} 847$ a month, $p=8 \%$. 
Compounded costs of living:

$$
K_{t, p}=k \times 12 \frac{e^{p t}-1}{p}
$$

Costs of living are compounded for 24 years, so:

$$
K_{18}=847 \times 12 \times \frac{e^{0,08 \times 18}-1}{0,08}=\operatorname{PLN} 409,189.40
$$

Human capital value $H_{0}$ :

$$
H_{0}=K=\operatorname{PLN} 409,189.40
$$

The annual labour costs are determined by the formula $p \times H(0)$ :

$$
\text { PLN 409, } 189.40 \times 0.08=\text { PLN 32,735.15 }
$$

Monthly compensation (labour costs):

$$
\frac{32735,15}{12 m-c y}=2727,93 \mathrm{zł}
$$

The resulting amount PLN 2,727.93 is the total compensation, so to estimate the gross compensation, one must reduce the amount by the contributions paid by the employer (for retirement pension: $9.76 \%$; for disability pension: $6.50 \%$; for accidents: $1.80 \%$; for the Labour Fund: $2.45 \%$; for the Employee Benefit Fund: 0.1\%; which totals: 20.61\%). The resulting gross compensation is PLN 2,261.78.

Based on the prior calculations of a minimum fair pay for a worker's family of four, presented below is an example showing the preservation of the human capital value in the context of generational change:

- value of the capital of one of the parents $(H(T))$ : PLN 409,189.40

- annual basic pay $(H(T) \times p)$ : PLN 32,735.15,

- monthly basic pay $\left(\frac{H(T) \times p}{12}\right)$ : PLN 2,728 (for two parents 5,456).

Assuming that the family pays the healthcare costs and the retirement security costs, the following solution has been adopted:

- healthcare and sickness insurance contribution 14\% of the compensation (PLN 764),

- retirement pension fund contribution 14\% of the compensation (PLN 764),

- income available to the family:

$$
\text { PLN 5,456 - PLN } 764-\text { PLN } 764=\text { PLN 3,928 }
$$


It can be noticed that after the contributions are paid, the income is PLN 3,820 , i.e. PLN 982 per capita. The amount is slightly higher than the subsistence minimum so it allows a model family to live decently and to prepare their children for work at least at the same level as the parents.

A pension fund regularly increased for 45 years makes it possible to save enough to retire at the age of 65 . The retirement pension amount will be equal to the basic pay. Assuming that the retirement pension contributions will be compounded at an interest rate of $3 \%$, we obtain the following value of the capital accumulated within the retirement fund:

$$
K E=F E \times \frac{(1+r)^{t}-1}{r}
$$

where: $K E$ - the capital accumulated for the retirement fund, $F E$ - retirement fund contributions, $r$ - retirement account interest rate, $t$ - period during which the contributions are paid.

$$
K E=764 \times 12 \times \frac{(1+0,03)^{45}-1}{0,03}=850056 \quad(\mathrm{PLN})
$$

Based on the data of the Polish Social Insurance Institution (ZUS), the average retired life in Poland is 15 years. So to guarantee retirement pension equal to the pay, the following amount of capital is required:

$$
K W=W \times \frac{(1+r)^{n}-1}{r} \times \frac{1}{(1+r)^{n}}
$$

where: $K W$ - the capital required to cover the $W$ contributions over the $n$ period.

$$
K W=5456 \times 12 \times \frac{(1+0,03)^{14}-1}{0,03} \times \frac{1}{(1+0,03)^{14}}=781600 \mathrm{zł}
$$

The above deliberations lead to a conclusion that the basic pay of $0.08 \times \mathrm{H}$ compensates the natural dispersion of an employee's human capital and makes it possible to preserve it over a longer period, i.e. it is sufficient to maintain a decent standard of life in the family, raise two children with a level of human capital not worse than that of their parents, and create a sufficient retirement pension fund for the parents.

\section{Conclusions}

The basic assumptions of the human capital model apply to an individual person. However, it must be stated that the growth of and payment for human capital is one of the most important economic processes taking place in a household. Human capital 
is unique and non-transferable. It is individual and assigned to a specific human capital holder. However, the non-transferability does not apply to the long period of generational change. An individual as the holder of the capital is responsible for preparing their successors (children) to work and function in the society. A family, or a household, can be defined as a managing micro-unit, usually connected through familial bonds, which produces income, distributes it for various purposes, provides services, produces goods and accumulates supplies (Pałaszewska-Reindl, Michna, 1986, p. 34).

Unfortunately, fair compensation does not guarantee that the human capital will be fully regenerated. Families may be guided by various preferences as to how to spend the income remaining at their disposal. Reasonable and creative actions of family members will additionally increase human capital. But lack of concern for one's health or careless use of the available funds, e.g. to abuse alcohol, will cause it to drop. It can be noticed that the impacts of the $m$ variable are incredibly important as they make it possible to increase the chance of preserving or growing human capital. The ability of a family to regenerate the human capital also largely depends on institutional determinants. Taxes and other mandatory withholdings from the pay make it much harder, or even impossible, to finance the reproduction of human capital (Oliwkiewicz, 2018).

\section{BIBLIOGRAPHY}

Bednarski, R., Dobija, M. (2003). What Should Accountant Teach and Intellectual Entrepreneur? In: R. Kwiatkowski, J. Sadlak (eds.), Intellectual Entrepreneurship Through Higher Education. Warszawa: Akademia Leona Koźmińskiego.

Borkowska, S. (2001). Strategie wynagrodzeń. Kraków: Oficyna Ekonomiczna.

Cieślak, I. (2008). Value of Human Capital and Wage Disparities. In: I. Górowski (ed.), General Accounting Theory. Evolution and Designe for Efficiency. Warszawa: Wydawnictwa Akademickie i Profesjonalne.

Deniszczuk, L. (1977). Wzorzec konsumpcji społeczno niezbędnej. Studia i Materiaty IPiSS, 10.

Dobija, M. (1998). How to Place Human Resources into the Balance Sheet. Journal of Human Resource Costing \& Accounting, 3 (1), 83-92. DOI: 10.1108/eb029044.

Dobija, M. (2002). Kapitał ludzki i intelektualny w aspekcie teorii rachunkowości. Przeglad Organizacji, 1, 8-13.

Dobija, M. (2003). Ewolucja koncepcji rachunkowości, kapitału i pieniądza. In: S. Sojak (ed.), Historia, wspótczesność i perspektywy rachunkowości w Polsce. Toruń: Wydawnictwo Uniwersytetu Mikołaja Kopernika.

Dobija, M. (2007). Abstract Nature of Capital and Money. In: M. Linda Cornwall (ed.), New Developments in Banking and Finance, (pp. 89-114). New York, Inc.: Nova Science Publishers. 
Dobija, M., Renkas, J. (2011). Zatratnaja funkcyja proizwodstwa w formirowanii zarabotnoj płaty na predprijatii. In: Zbirnych naukowych prac Czerkaskogo derżawnogo technologicznogo uniwersytetu, Series: Ekomoniczni nauky: Wypusk 27, Czerkasy: CzDTU.

Dobija, M. (2009). Natura zysku i tempo wzrostu kapitału. In: H. Buk, A. M. Kostur (eds.), Zintegrowany system pomiarów dokonań w rachunkowości. Katowice: Prace Naukowe Akademii Ekonomicznej im. K. Adamieckiego w Katowicach.

Dobija, M. (ed.). (2010). Teoria pomiaru kapitalu i zysku. Kraków: Uniwersytet Ekonomiczny w Krakowie.

Karaszewska, H. (2003). Ewolucja wynagrodzeń w Polsce w okresie zmian systemu ekonomicznego. Toruń: Wydawnictwo Uniwersytetu Mikołaja Kopernika.

Kozioł, W. (2010). Pomiar kapitatu ludzkiego jako podstawa ksztattowania relacji płac w organizacji. Doctoral thesis. Kraków: Uniwersytet Ekonomiczny w Krakowie.

Kurek, B. (2011). Hipoteza deterministycznej premii za ryzyko. Monografie: Prace Doktorskie, 10, Kraków: Wydawnictwo Uniwersytetu Ekonomicznego w Krakowie.

Kurowski, P. (2018). Informacja o poziomie minimum socjalnego w czerwcu 2018 r. Retrieved from: https://www.ipiss.com.pl/?zaklady=minimum-socjalne (2018.09.25).

Oliwkiewicz, B. (2016). Wynagrodzenie godziwe absolwenta studiów wyższych w Polsce w aspekcie modelu kapitału ludzkiego. Nierówności Społeczne a Wzrost Gospodar$c z y, 47,481-491$. DOI: 10.15584/nsawg.2016.3.35.

Oliwkiewicz, B. (2018). Godziwa płaca minimalna jako determinanta zintegrowanego rozwoju. Nierówności Społeczne a Wzrost Gospodarczy, 54, 370-371. DOI: 10.15584/ nsawg.2018.2.27.

Pałaszewska-Reindl, T., Michna, T. (1986). Gospodarstwo domowe - ekonomiczna i organizacyjna baza rodziny polskiej. In: T. Pałaszewska-Reindl (ed.), Polskie gospodarstwo domowe: życie w kryzysie. Warszawa: Instytut Wydawniczy Związków Zawodowych.

Renkas, J. (2012). Empiryczny test modelu kapitału ludzkiego i minimalnych wynagrodzeń. Nierówności Społeczne a Wzrost Gospodarczy, 24, 180-191.

\section{Summary}

The family is the only supplier of human capital to the labour market. A prerequisite for maintaining a proper level of human capital in the household is to provide the employee with a fair wage. A good wage is one that gives the opportunity to reproduce human capital at least on the same level, both in the short and long term. The growth and method of paying human capital is one of the main economic processes taking place in the household. Human capital has a unique character that is characterized by inalienability. The capital is individual and assigned to a specific holder of human capital. However, inalienable does not apply to the long period of generational exchange. Man, as the owner of capital, prepares his successors (children) to provide work and functioning in society. However, a reasonable remuneration does not guarantee full reconstruction of human capital. Families may be guided by various preferences when it comes to using their income at their disposal. Reasonable and creative actions of family members will lead to an additional increase in human capital. However, the lack of care for health or the use of available resources in a careless manner, e.g. alcohol abuse will lower its value. The purpose of this article is to present the role of 
the family in shaping human capital as well as an attempt to estimate the minimum fair remuneration in Poland, which will enable the reconstruction of human capital in the short and long-term through generational exchange.

Keywords: minimum wage, human capital, fair remuneration, work.

\section{Ochrona kapitału ludzkiego przed deprecjacją jako podstawowa przesłanka wynagradzania}

\section{Streszczenie}

Rodzina jest jedynym dostawcą kapitału ludzkiego na rynek pracy. Warunkiem koniecznym utrzymania odpowiedniego poziomu kapitału ludzkiego w gospodarstwie domowym jest zapewnienie pracownikowi płacy godziwej. Godziwa płaca to taka, która daje możliwość odtworzenia kapitału ludzkiego przynajmniej na tym samym poziomie zarówno w krótkim, jak i w długim okresie. Wzrost i sposób opłacania kapitału ludzkiego to jeden z głównych procesów ekonomicznych mających miejsce w gospodarstwie domowym. Kapitał ludzki ma unikalny charakter, który cechuje się niezbywalnością. Kapitał jest indywidualny i przypisany do konkretnego posiadacza kapitału ludzkiego. Jednakże niezbywalność nie dotyczy długiego okresu, jakim jest wymiana pokoleń. Człowiek, jako posiadacz kapitału, prowadzi przygotowania swoich następców (dzieci) do świadczenia pracy i funkcjonowania w społeczeństwie.

Godziwe wynagrodzenie jednak nie gwarantuje pełnego odtworzenia kapitału ludzkiego. Rodziny mogą się kierować różnymi preferencjami, jeśli chodzi o wykorzystanie dochodu pozostającego w ich dyspozycji. Rozsądne i twórcze działania członków rodziny doprowadzą do dodatkowego wzrostu kapitału ludzkiego. Natomiast brak troski o zdrowie lub wykorzystywanie dostępny środków w niefrasobliwy sposób, np. nadużywanie alkoholu, spowodują obniżenie jego wartości.

Celem niniejszego artykułu jest przedstawienie roli rodziny w kształtowaniu kapitału ludzkiego, jak również próba oszacowania minimalnego wynagrodzenia godziwego w Polsce, które umożliwi odtworzenie kapitału ludzkiego w krótkim i w długim okresie poprzez wymianę pokoleniową.

Słowa kluczowe: płaca minimalna, kapitał ludzki, wynagrodzenie godziwe, praca.

JEL: E24, J24. 